\title{
Are International Human Rights Organizations Effective in Protecting Religious Freedom?
}

\author{
Lihui Zhang \\ Department of Political Science, University of Oklahoma, Norman, OK 73019, USA; lihui.zhang-1@ou.edu
}

check for updates

Citation: Zhang, Lihui. 2021. Are International Human Rights Organizations Effective in Protecting Religious Freedom? Religions 12: 479 https://doi.org/10.3390/rel12070479

Academic Editors: Timothy Shah and Nathan A. Berkeley

Received: 21 April 2021

Accepted: 23 June 2021

Published: 28 June 2021

Publisher's Note: MDPI stays neutral with regard to jurisdictional claims in published maps and institutional affiliations.

Copyright: (C) 2021 by the author. Licensee MDPI, Basel, Switzerland. This article is an open access article distributed under the terms and conditions of the Creative Commons Attribution (CC BY) license (https:/ / creativecommons.org/licenses/by/ $4.0 /)$.

\begin{abstract}
This paper examines whether international human rights organizations (HROs) influence the protection of religious freedom, and whether the effect is different on the protection of religious rights for institutions versus individuals. This study not only reveals the institutional and individual dimensions of religious restrictions with an exploratory factor analysis, but also uses fixed effects models to analyze cross-national time-series data covering 1990-2003. The results indicate that the domestic presence of HROs has a positive effect on reducing both aggregate religious restrictions and the two dimensions of religious restrictions.
\end{abstract}

Keywords: institutional religious restrictions; international human rights organizations

\section{Introduction}

The global community has made great efforts in the protection of human rights since the end of WWII. The International Bill of Human Rights sets the protection of human rights as a common standard for all peoples and nations and intends to promote these rights by "progressive measures, national and international, to secure their universal and effective recognition and observance, both among the peoples of Member States themselves and among the peoples of territories under their jurisdiction" (pages 1-2, The International Bill of Human Rights). According to Article 4 in International Covenant on Civil and Political Rights, religious freedom is one of the non-derogable rights. Due to this it has a special status in international human rights regimes and is broadly supported by transnational activism. However, due to the lack of enforcement mechanisms in human rights regimes, efforts to improve human rights mainly are incentive and norm based. States are expected to improve rights practices under the criticism on the international stage (Brysk 1993; Hendrix and Wong 2013; Khagram et al. n.d.; Sikkink 1993). International human rights organizations are powerful in the protection of human rights through transnational advocacy networks, which transmit information on domestic rights violations and mobilize the international audience to pressure states to change their behaviors (Keck and Sikkink 1999). States are also expected to change their behavior in human rights protection in a spiral model, in which they eventually internalize international human rights standards and change behaviors despite their initial denial (Risse et al. 1999).

Recent scientific studies have provided extensive evidence of the positive effects of HROs on rights protection. HROs not only improve human rights protection directly, but also exert influence indirectly through the third actors, such as western democracies who use information HROs provide (Peksen 2009, 2012). However, there are two shortcomings in the current state of research in the study of HROs on human rights protection. First, the current literature in the scientific study of international human rights narrowly focuses on the protection of physical integrity. Second, current literature has not given enough attention to the dual nature of human rights: the individual and institutional dimensions.

This study not only expands the scope of international human rights study into religious freedom, but also takes account of both individual and organizational dimensions of religious rights. The factor analysis of government religious restriction index clearly 
indicates why the institutional and individual restrictions should be considered separately. I use fixed effect models in this study to examine whether international human rights organizations influence the level of religious restrictions over time. It is a contribution to the study of religious freedom, because most of the past research has focused on a set of point in time. I find that the domestic presence of HROs has a positive effect on the protection of aggregate religious rights, both for institutional and individual religious rights over time. However, it does not mean that differentiating institutional and individual religious rights is not necessary. In fact, the statistical models show that these two categories of rights are associated with different demographics and characteristics of a country. For example, restrictions on religious institutions tend to be higher in societies with a relatively homogenous religious scene or an established religion, but religious individual rights are not influenced by those factors. This has important implications for our understanding of where religious institutions face the greatest obstacles to their autonomy.

This study adds to the existing literature in the following ways: first, it enriches the scientific study of international human rights by seriously investigating religious rights, given the overemphasis of physical integrity in current scholarship. I argue that religious rights represent spiritual integrity and are equally important as physical integrity. Expanding the scope of the human rights enables us to have a comprehensive understanding of the factors could help protect human rights, but also advances theoretical development in the field of human rights. Second, this study takes account institutional religious rights by recognizing and differentiating the individual and institutional/organizational dimensions of human rights. Human rights in general have both public/communal and private dimensions. Without taking account of both dimensions, the study of effects of human rights protections is not complete. Overlooking the organizational (or institutional) dimension of human rights also hinders theoretical and policy development in human rights studies. In showing the vital role of HROs in advancing religious freedom, this paper indicates the need for human rights organizations, such as the Religious Freedom Institute, with a special focus on religious freedom. Not all human rights organizations demonstrate an awareness of the unique nature of religious freedom, or how violations of this right affect the fate of general human rights around the globe.

\section{Literature Review: HROs Advocacy and Human Rights Practices}

Early work in empirical studies provide theoretical foundations for the effects of $\mathrm{HRO}$ advocacy on human rights protection. International human rights organizations (HROs) enjoy advantages in transnational networks and information to better hold states accountable for their rights violations. The domestic presence of HROs can pressure oppressing regimes from below through the support for local social movements, and from above through the third-party states that cite reports generated by HROs (Peksen 2009, 2012). In reality, domestic actors often cannot pressure states directly, therefore, they seek transnational advocacy networks to bring material and moral leverage to change states' behavior (Keck and Sikkink 1999). In the spiral model of human rights norm diffusion, we see a discursive causal process linking HRO advocacy on human rights practices. Rights violating states often first deny the abuses alleged by HROs, but repressive states will institutionalize human rights provisions, eventually internalize human rights norms, and change their behavior under the concentrated and continued pressure from HROs and the international community (Risse et al. 1999).

Echoing the spiral model of human rights norm diffusion, the world society approach in sociology offers another theoretical perspective on how international institutions and culture influence the behaviors of nation states and domestic actors. The expansion of HROs contributes to the extensive horizontal institutionalization in world society, which defines the meaning and identity of various actors and appropriate patterns of activities. Therefore, HROs lead to the adoption of norms of human rights protection among nation states and domestic actors through collective purposes and identities constructed by world culture (Meyer et al. 1997; Simmons et al. 2008; Tsutsui and Wotipka 2004). 
Recent quantitative cross-national studies provide extensive evidence of the relationship between HROs and human rights practices. Even though it is quite consistent that increases in HRO shaming lead to improvement in human rights (DeMeritt 2012; Krain 2012; Murdie 2014), rights violators are only vulnerable to international pressure and improve their human rights when HROs criticize them (Franklin 2008; Murdie 2014). For example, when women's rights protection is examined specifically, the effect of HROs is more nuanced. Women's rights international non-governmental organizations (WROs) are effective in improving government respect for women' rights in general. However, a targeted naming and shaming publicity strategy is necessary to exert pressure on the government to enforce women's internationally recognized rights (Murdie and Peksen 2015). Similarly, Murdie and Davis (2012) find that HROs presence, paired with HROs targeting with third party pressure can improve human rights conditions. The domestic presence of HROs leads to naming and shaming campaigns, and more attention and condemnation of the human rights abuses by Amnesty international (Meernik et al. 2012). This indicates that the domestic presence of HROs can have effect on the rights protection indirectly through naming and shaming campaigns.

More studies render nuanced findings. The effects of the presence and activities of HROs might be conditional. The influence of naming and shaming is conditioned by the level economic integration condition in a country (Franklin 2008); HRO criticism tends to work better when the countries have stronger ties with other countries. HRO activities also have different effects depending on the context and types of rights violations. The presence of $\mathrm{HRO}$ members in neighboring countries increases the probability of human rights improvements, but that is conditional on the ability of the groups to freely move across borders (Bell et al. 2012). The effect of human rights advocacy might also be contingent upon regime type. HRO activity provides information, which matters more for actors engaged in covert abuses like torture but not for actors engaged in overt abuses like death penalty. Therefore, advocacy can lead to improved outcomes in autocracies, which tend to engage in covert abuses that HRO activity publicizes. Democracies, on the other hand, tend to engage in overt abuses, like the death penalty, and HRO activity does not provide new info to the public (Hendrix and Wong 2013). Emilie M. Hafner-Burton (2008) finds that naming and shaming have negative relationships for some rights, but positive relationships for other rights. Public criticism by NGOs, the UN, and the media improves political rights, but does not reduce political terror (killings and beatings), because governments' capacities for human rights improvements vary across types of violations. Governments strategically use some violations to offset other improvements they make in response to international pressure. In addition, central governments might not have the ability to immediately improve human rights conditions happening on a local level even if they intend to (Bagwell and Clay 2017), because of the state capacity. The effect of human rights institutions might also condition on time. Cole and Ramirez (2013) find that the effect of national human rights institutions not only differs by the type of rights, but also by time: right violation increases initially but decreases later.

HROs also have an indirect effect on human rights conditions through the third parties. According to the boomerang (Keck and Sikkink 1999) and spiral models (Risse et al. 1999), advocacy groups not only directly pressure violating states, but also mobilize third parties, such as international organizations and western democracies, to pressure targeted states to change behaviors. HROs can provide information and set the agenda for other international actors through targeting campaigns. For example, the United States uses information provided by Amnesty International to pressure other states to change human rights conditions (Brysk 1993). Even though HROs, as moral agents, apply moral pressure to violators, third party actors can apply material pressure to change abusing states' behaviors. States are also expected to have better human rights practice and better compliance with international law when they have joined more inter-governmental organizations, because violation of their legal obligations in the international communities 
magnifies shaming effects (Keck and Sikkink 1999; Goodman and Jinks 2004; Risse et al. 1999).

Despite of the extensive studies done on the effect of HROs on human rights, there are two shortcomings in the current state of literature. There is a narrow focus on the protection of human rights. The extant studies have mostly focused on the protection of physical integrity rights, so there is a need to explore whether the mechanism of HROs work the same for other kinds of rights. Studies have discovered that HROs have different effects on different kinds of rights (Hafner-Burton 2008; Hendrix and Wong 2013). Expanding the scope of human rights can strengthen the external validity of the results of current statistical analysis in human rights studies. As such an effort, this study focuses on the religious rights. Religious freedom, as a spiritual integrity right, is often marginalized in the scientific study of international human rights, but it is a recognized international norm in human rights, and of great importance to the dignity and wellbeing of individuals and groups with religious beliefs. Given the wide spread of religious restrictions (Fox 2015, 2021) and discrimination (Fox 2014), and the detrimental consequences of religious restrictions and discrimination on human rights protection (Fox 2008) and ethnic conflicts (Fox 2000), it is imperative to examine whether HROs can improve the protection of religious freedom. As religion plays an increasing role in international relations in theory and practice (Fox 2001; Sandal and Fox 2013), this study will enrich the literature in IR by providing theoretical advancement and empirical findings in the intersection between religion and human rights study.

Another shortcoming in the current literature is the lack of the examination of the two dimensions of human rights. Most studies focus on the protection of individual rights, and even the definition of human rights is restricted to individuals (Donnelly 2013). However, human rights should include the rights for both individuals and groups. A new study indicates that institutional and individual religious restrictions towards minorities can be predicted by different variables (Finke et al. 2017). The individual dimension is private; the organizational dimension of human rights is social and collective. For some kinds of human rights, such as religious rights and workers' rights, these two dimensions are integral parts. The individual practice is limited without the acknowledgment and protection of the group dimension of the freedom. For example, religious individuals do not have full freedom of religion when they are not allowed to have a church, just as workers do not have labor rights if they are not allowed to form a union. This study contribution to scholarship by taking account of both dimensions of religious rights and examining the effects of HROs on the protection of religious freedom.

\section{Theory and Hypothesis}

HROs can influence the protection of religious freedom through three channels. First, the local HROs can gather documentation (Brysk 1993) about the rights violations by the government. HROs operate on a local level in the field; therefore, they can collect the firsthand information on the human rights abuse including religious restrictions. Second, HROs can also mobilize human rights movements for the better treatment of the citizens by governments. HROs also know international human rights standards and states' legal international commitments, thus, they can mobilize and provide resources to the religious community to fight for their rights. Third, HROs can provide assistance to human rights groups (Brysk 1993) to overcome the political barriers they face when they fight for their rights on the local level. Religious rights should conform to a similar mechanism.

Therefore, I hypothesize:

Hypothesize 1 (H1). The domestic presence of HROs decreases the restrictions of aggregate religious rights.

Would HROs influence how governments treat religious institutions and individuals? Religious freedom inherently includes institutional and individual rights (Scolnicov 2010), and it would not be appropriate to assume that HROs have the same effect on the 
protection of these two dimensions of rights. For the domestic presence of HROs, different mechanisms might operate for private individuals versus more public institutions.

Religious individual rights and group rights are different in their visibility. Religious individual rights have an emphasis on the expression of one's belief, while the institutional rights concern group identity and functioning (Scolnicov 2010). Rights violation for institutions are overt, for individuals more covert. Therefore, HROs work more directly to pressure governments to improve institutional human rights and indirectly to improve individual human rights.

Religious institutions have a social, communitarian dimension (Scolnicov 2010). Just as Finke's definition of religious groups as "collectives that promote religious belief, symbols, and practices" (Finke 2013, p. 299). Therefore, religious groups enjoy a higher visibility in comparison to individuals, and restrictions of religious groups are correspondingly more visible. For example, the favoritism of the Orthodox church and restrictions of other religious institutions by the Russian government are highly visible and well known. Religious organizations have the natural advantage such as resources and skills to mobilize themselves for political actions (Fox 2018). The restrictions of religious organizations are usually conducted overtly based on the claims of disruptions of social orders, subversion of state authority, etc. Human rights social movements led by religious actors can cause political disruptions in society and potentially lead the governments to tighten their control of religious groups and even violently crack down. HROs can mediate between the governments and religious groups, and work with religious community to avoid the repercussions from the political disruption. HROs can decrease the severity of restrictions on religious groups by providing assistance to lessen the political repercussions from social movements.

Thus, I hypothesize that:

Hypothesize 2 (H2). The domestic presence of HROs decreases the restrictions of religious institutions.

In contrast, religious individuals are relatively less visible and restrictions on religious practice of individuals are more covert. Information on the restrictions and persecution of religious individuals can be hidden intentionally from the public and media by authoritarian regimes to avoid criticism. On the other hand, violation of religious rights of individuals is often conducted by the local officials and police, therefore, there is a principal agent problem due to the state capacity (Englehart 2009). States are restricted by their capacity to monitor abuses on an individual level and evidence of violations is harder to collect on a local level. The local HROs can gather information on rights violations and then transmit overseas through transnational advocacy networks. When HROs launch naming and shaming campaigns targeting the states on religious restrictions of individuals, $\mathrm{HROs}$ provide new information to the public and international audience. Therefore, the naming and shaming campaigns would pressure states to improve rights protection due to their vulnerability to moral pressure on their reputations. States can be pressured from above by targeting campaigns of HROs and other third parties. HROs have extensive transnational advocacy networks and can engage in naming and shaming campaigns to induce material and reputational costs on rights violating states. In response, rights violating states might deny such practices at first, but will eventually improve their rights protection under pressure with reputational concerns (Risse et al. 1999).

HROs can also improve the condition of human rights on an individual level in a bottom-up process. The improvement of rights protection is a product of the combined efforts from the states, citizens, and other domestic and international groups. HROs can provide information to individuals and mobilize them to initiate legal claims in domestic legal systems (Simmons 2009). HROs can also initiate information campaigns to educate the domestic population on human rights issues (Davis et al. 2012). The embeddedness of a country in global civil society and international flows of human resources are important predictors for citizens' participation in human rights campaign. If citizens have a member- 
ship in HROs, they are more likely to participate in the global human rights movements (Tsutsui 2006).

Hypothesize $3 \mathbf{~ ( H 3 ) . ~ T h e ~ d o m e s t i c ~ p r e s e n c e ~ o f ~ H R O s ~ d e c r e a s e s ~ t h e ~ r e s t r i c t i o n s ~ o f ~ r e l i g i o u s ~}$ individuals.

\section{Data and Methods}

By aggregating data needed for all the variables in this research, I have created a panel dataset. After performing list-wise deletion, the data includes 118 entities (countries) across 14 years from 1990 to 2003. Due to the limitation of the data on HROs (the international human rights organization) (Smith and Wiest 2005), this study is limited to the above years.

The dependent variables are aggregate religious restrictions, institutional religious restrictions, and individual religious restrictions. The aggregate religious restrictions are the sum of all religious restriction indicators from the index on Regulation of and Restrictions on the Majority Religion and All Religions in Religion and State Dataset Round 3 (RAS 3) dataset (The Association of Religion Data Archives). The RAS3 dataset uses detailed indicators to measure Regulation of and Restrictions on the Majority Religion and All Religions and includes the measures for religious restrictions towards institutions and clergy, and individuals. Each indicator in the index ranges from 0 (no restrictions) to 3 (large scales of restrictions). The descriptive statistics are in Table 1.

The other two dependent variables-institutional religious restrictions and individual religious restrictions-are also constructed from the above index with exploratory factor analysis. More detailed explanations of the two variables and the factor analysis are to follow. The descriptive statistics are in Table 1.

The main independent variables are the measures for the presence of HROs. The presence of HROs is operationalized as the number of HROs within each country. This variable is measured by the number of INGOs listed in the Yearbook of International Organizations with a human rights focus with members or volunteers in a specific country in a specific year (Smith and Wiest 2005).

I also control the following usual suspects influencing human rights levels. Economic development is expected to be positively related to states' respect for human rights according to past research (Mitchell and McCormick 1988; Poe and Tate 1994; Poe et al. 1999; Keith et al. 2009). Specifically, stronger economies have fewer government religious restrictions (Grim and Finke 2010). However, the effects of economic growth are mixed. Economic growth can expand the resource base and reduce the economic and social stress, so the governments are less likely to use repression. On the other hand, rapid economic growth also can increase instability which induce the states to resort to coercion (Poe and Tate 1994). In this study, economic development is measured by the GDP and economic growth is measured by percentage growth in GDP.

Population size is positively related to repression according to studies (Poe and Tate 1994; Poe et al. 1999; Keith et al. 2009; Richards et al. 2001). Population size is also positively related to religious restrictions (Finke et al. 2017). To operationalize the effects of population on the abuse of human rights through repression, I will use the total national population to measure the population size. The data for the population size for the 118 countries are from the World Bank development indicators.

The type of political regime also matters for religious freedom. Most of the research in the areas of international human rights law also find that democracy is positively correlated with better practice in human rights law compliance with different approaches (Poe and Tate 1994; Poe et al. 1999; Keith et al. 2009; Richards et al. 2001; Hathaway 2002; Dai 2005). Non-democratic countries repress religion more than others (Sarkissian 2015; Finke and Martin 2014; Finke 2013; Grim and Finke 2010). Democracies have political competition based on the multi-party system. Thus, repression of religions will face political retribution. In this study the democracy variable is measured by the Polity IV score created by Center 
for Systemic Peace. It ranges from -10 to +10 measuring the autocratic political system to democratic political system.

Regime duration matters for religious freedom too. Older democracies have fewer government restrictions on religious freedoms (Grim and Finke 2010), thus regime duration matters for religious restrictions. Newer regimes and well-established regimes may also have different tendencies to respect human rights (Hafner-Burton and Tsutsui 2005; Hathaway 2002). This variable is measured by the regime durability in Polity IV data.

Scholars have also found that internal and external wars in countries are often related to the regimes' lower respect for human rights (Poe and Tate 1994; Poe et al. 1999; Rasler 1986). The data for internal and external wars are from the Major Episodes of Political Violence and Conflict Regions, 1946-2015, by the Center for Systemic Peace. International wars are measured by the number of international wars the states have participated in; the internal wars are measured by the amount of the civil war and ethic war the states experienced.

The states' integration into international social society is also an important factor. Global economic interdependence is also important factor influencing human rights protection in countries (Hathaway 2002; Hafner-Burton and Tsutsui 2005). This variable is measured by the percentage of gross domestic product made up by trade, and the source of the data is from World Development Indicators.

Another factor could affect the protection of religious freedom is judiciary independence. An independent judiciary advances religious freedoms (Finke and Martin 2014). If a state with an independent judiciary violates human rights norms, a citizen can bring a claim against it in court. However, citizens in states without independent judiciary would have no resources with which to launch an attack against the state. I adopt the measure provided by CIRI Human Rights Data Project. The levels of judicial independence across countries are coded as 0 for "not independent", 1 for "partially independent" and 2 for "generally independent".

Studies find that percentage of the Muslims in a country is positively related to religious restrictions (Finke and Martin 2014), while the percentage of Christians is negatively related to religious restrictions (Grim and Finke 2010). I included two variables measuring percentages of Muslims and Christians, which are provided in World Religion Data by the Correlates of War Project.

Religious pluralism is an important factor influencing the degree of religious freedom in a society. Rulers grant religious liberties to the public based on their strategic considerations on their political and economic interests. The needs for political figures to balance competing interests in a religiously plural context are important driving forces for the religious liberty (Gill 2007). Religious pluralism is conducive to religious freedom, because it provides a marketplace for different religions to compete with each other for resources and motivate them to grow (Stark and Finke 2000; Gill 2007). Thus, religious liberty is more likely to be in place where there is religious diversity. I created a measure of religious homogeneity using the data of percentages of different religious groups by World Religion Data through the method of Herfindahl-Hirschman Index measure. It is a continuous measure ranging from 0 to 1 .

Having an official state religion is often related to religious repression (Finke 2013). When states establish one religion, other religions are in a disadvantaged place in a competition. Other religions in the society could threaten the legitimacy of its institutions and the favored treatment it receives from the state. To prevent unwanted competition and secure more authority and resources, the dominant religion often seeks an alliance with the state. On the other hand, states often build their legitimacy off the established religion. Keeping the status of dominant religion is also in states' interest to their rule. To secure and maintain this alliance, the state often restricts all other religions and discriminates against minority religions to keep the advantaged place the dominant religion (s) holds. I include a measure for religious establishment-Official Religion-which is from Religion and State Dataset Round 3 (RAS 3) dataset (The Association of Religion Data Archives). I recoded 
this variable into a dummy variable; 1 means the state has established religions, while 0 means the state has no official religions.

The basic data statistics of the above variables are in Table 1 below.

Table 1. Descriptive Statistics.

\begin{tabular}{|c|c|c|c|c|c|c|c|}
\hline Statistic & $\mathbf{N}$ & Mean & St. Dev. & Min & $\operatorname{Pctl}(25)$ & $\operatorname{Pctl}(75)$ & Max \\
\hline Aggregate Religious Restrictions & 1494 & 6.7 & 8.1 & 0 & 1 & 9 & 43 \\
\hline Institutional Religious Restrictions & 1494 & 0.2 & 0.4 & 0.0 & 0.0 & 0.3 & 1.8 \\
\hline Individual Religious Restrictions & 1494 & 0.2 & 0.2 & 0.0 & 0.0 & 0.3 & 1.5 \\
\hline HROs & 1494 & 38.4 & 23.4 & 1 & 20.7 & 51 & 139 \\
\hline Democracy & 1494 & 3.8 & 6.3 & -10 & -2 & 9 & 10 \\
\hline Population (logged) & 1494 & 16.2 & 1.5 & 11.2 & 15.3 & 17.1 & 20.8 \\
\hline GDP (logged) & 1494 & 23.7 & 2.2 & 18.9 & 22.1 & 25.4 & 30.1 \\
\hline GDP Growth Rate & 1494 & 3.2 & 5.3 & -50.2 & 1.6 & 5.6 & 35.2 \\
\hline Trade(\%GDP) & 1494 & 71.4 & 38.1 & 11.1 & 46.3 & 85.7 & 280.4 \\
\hline Internal War & 1494 & 0.7 & 1.6 & 0 & 0 & 0 & 10 \\
\hline External War & 1494 & 0.03 & 0.3 & 0 & 0 & 0 & 4 \\
\hline Regime Duration & 1494 & 22.4 & 31.2 & 0 & 4 & 30 & 194 \\
\hline Judiciary Independence & 1494 & 1.2 & 0.7 & 0 & 1 & 2 & 2 \\
\hline Islam (\%) & 1494 & 0.2 & 0.4 & 0.0 & 0.002 & 0.3 & 1.0 \\
\hline Christian (\%) & 1494 & 0.6 & 0.4 & 0.0 & 0.1 & 0.9 & 1.0 \\
\hline Religious homogeneity & 1494 & 0.8 & 0.2 & 0.0 & 0.7 & 1.0 & 1.0 \\
\hline Religious Establishment & 1494 & 0.2 & 0.4 & 0 & 0 & 0 & 1 \\
\hline
\end{tabular}

\section{Statistical Modeling}

Due to the considerable heterogeneity among the countries examined in this study as panel data, the pooled OLS models may not be proper methods to estimate the effects of the independent variable on religious restrictions. This study uses fixed effect models to examine the "within" effect of the international human rights organizations, taking account of both the heterogeneity across countries and years. The estimates of this study should reveal whether states change behavior in religious freedom after they ratify the treaty within the time frame in this study. I will test the following models:

Fixed Effect Models: Religous Restrictions $=\left(\alpha_{i}+\theta_{t}\right)+\beta_{1} H R O s+Z_{i t}+\varepsilon_{i t}$

In this model, $\alpha_{i}$ is the individual effect and $\theta_{t}$ is the time effect. $\alpha_{i}$ captures the effects that are specific to some countries but constant over time, whereas $\theta_{t}$ captures effects that are specific to some time period but constant over countries. Controlling for time effect is necessary. First, important international events such as the end of Cold War and the deepening of globalization happened during 1990-2008. Additionally, there is an increasing trend in the past decades that human rights data are inflated due to the higher of accountability and better data collection methods (Fariss 2017). Taking account of fixed effect of years helps alleviate this problem. $\varepsilon_{i t}$ is the error term in this model. $Z_{i t}$ is a matrix of control variables including political regime, judiciary independence, population, GDP size, GDP growth rate, the proportion of trade in GDP, internal war and external war, the regime duration, percentage of Christians and Muslims, religious homogeneity and establishment of religion.

\section{Findings}

\subsection{Building Variables Representing Two Dimensions of Religious Restrictions}

The factor scores are derived from the government religious restriction index (NX) from the RAS3 dataset. The NX index is about government restrictions on all religions and majority religions, and it comprehensively covers government religious restrictions in various dimensions. 
To discover the latent dimensions of religious restrictions, I run exploratory factor analysis on the NX index. I performed orthogonal rotation when I generated the factors, so the two factors have a minimal correlation. The correlation between two factors is 0.09 $(p<0.05)$. Based on an examination of both the eigenvalues and the questions, I decided to limit the number of factors to two. Based on two different kinds of rotations of the factor analysis, the patterns of the two factors seem quite stable. As shown in Table 2, the first factor has high loadings mostly on items focusing on whether any level of government imposes limitations on religious organizations, such as churches, schools and associations. For example, items regarding government restrictions on religious parties, government restrictions on religious members and organizations not sponsored by the states, and government restrictions on religious clergy and/or organizations engaging in public political speech all have high loadings on factor 1. I labeled this factor as "institutional restrictions". Countries, such as Egypt, Iraq, Saudi Arabia and Syria have noticeably high scores on this factor, which indicates that Middle Eastern countries tend to impose higher religious restrictions on organizations than other countries. This could be explained by application of Islamic law in such countries, which puts restrictions on religious groups, but also how theocratic regimes control religions in general.

As shown in Table 2, the second factor has high loadings on items concerned with the government restrictions on individuals' expression and practice of their religions, such as public observance of religious practices, public religious speech, and access to places of worship. For instance, items regarding restrictions on the public observance of religious practices, restrictions on access to places of worship, whether people are arrested for religious activities are all have high loadings on factor 2 . Thus, the second factor is focused on the religious restrictions on individual practice of religion and is labeled as "individual restrictions". Countries, such as China, North Korea, Cuba, Turkmenistan, Uzbekistan and Vietnam scored high on this factor in comparison to the rest of the countries, which implies that these countries impose higher levels of restrictions on individual religious practice. This could be explained by the legacy of the totalitarian regimes from the post-communist states that controlled all aspects of social life.

As the indexes load upon two dimensions-institutional and individual religious restrictions, they can be categorized into these two groups. I followed Grim and Finke (2006)'s methods to generate the indexes for the two dependent variables. As the indexes generated from factor score and raw score additive approach are highly correlated, I will only present the latter results. The simple additive methods have the advantage of being simple and parsimonious. In order to keep the index to the same scale as the single index to facilitate the interpretation of the statistical models, I use the following equation to calculate the indexes for institutional religious restrictions and individual religious restrictions:

Institutional/Individual Religious Restrictions $=$ sum of raw scores of indicators /number of indicators

Table 2. The Factor Analysis Loadings for Government Religious Restrictions (NX) Index.

\begin{tabular}{lcc}
\hline & \multicolumn{2}{c}{ Factor Loadings } \\
\cline { 2 - 3 } & Insitutional Religous Restrictions & Individual Religious Restrictions \\
\hline Restrictions on religious political parties. & 0.501 & -0.109 \\
\hline $\begin{array}{l}\text { The government restricts or harasses religious } \\
\text { members and organizations not sponsored by } \\
\text { the states. }\end{array}$ & 0.827 & -0.079 \\
\hline $\begin{array}{l}\text { Restrictions on formal religious organizations } \\
\text { other than political parties. }\end{array}$ & 0.523 & 0.310 \\
\hline $\begin{array}{l}\text { Restrictions on the public observance of religious } \\
\text { practices. }\end{array}$ & -0.088 & 0.786 \\
\hline
\end{tabular}


Table 2. Cont.

\begin{tabular}{|c|c|c|}
\hline & \multicolumn{2}{|c|}{ Factor Loadings } \\
\hline & Insitutional Religous Restrictions & Individual Religious Restrictions \\
\hline $\begin{array}{l}\text { Restrictions on religious activities outside of } \\
\text { recognized religious facilities. }\end{array}$ & -0.088 & 0.786 \\
\hline Restrictions on public religious speech. & 0.365 & 0.460 \\
\hline Restrictions or monitoring of sermons by clergy. & 0.847 & -0.131 \\
\hline $\begin{array}{l}\text { Restrictions on clergy and/or religious } \\
\text { organizations engaging in public political speech } \\
\text { or on political activity in or by religious } \\
\text { institutions. }\end{array}$ & 0.503 & -0.054 \\
\hline Restrictions on access to places of worship. & 0.187 & 0.626 \\
\hline $\begin{array}{l}\text { Restrictions on the publication or dissemination } \\
\text { of written religious material. }\end{array}$ & 0.400 & 0.534 \\
\hline People are arrested for religious activities. & -0.115 & 0.956 \\
\hline $\begin{array}{l}\text { Restrictions on religious public gatherings that } \\
\text { are not placed on other types of public gathering. }\end{array}$ & -0.132 & 0.783 \\
\hline $\begin{array}{l}\text { Restrictions on or regulation of religious } \\
\text { education in public schools. }\end{array}$ & 0.574 & -0.249 \\
\hline $\begin{array}{l}\text { Restrictions on or regulation of religious } \\
\text { education outside of public schools or general } \\
\text { government control of religious education. }\end{array}$ & 0.552 & 0.233 \\
\hline $\begin{array}{l}\text { The government appoints or must approve } \\
\text { clerical appointments or somehow takes part in } \\
\text { the appointment process. }\end{array}$ & 0.540 & 0.132 \\
\hline $\begin{array}{l}\text { The government legislates or officially influences } \\
\text { the internal workings or organization of religious } \\
\text { institutions and organizations. }\end{array}$ & 0.573 & 0.058 \\
\hline $\begin{array}{l}\text { Laws governing the state religion are passed by } \\
\text { the government or need the government's } \\
\text { approval before being put into effect. }\end{array}$ & 0.320 & -0.096 \\
\hline $\begin{array}{l}\text { State ownership of some religious property or } \\
\text { buildings. }\end{array}$ & 0.392 & 0.046 \\
\hline $\begin{array}{l}\text { Conscientious objectors to military service are } \\
\text { not given other options for national service and } \\
\text { are prosecuted. }\end{array}$ & 0.408 & 0.009 \\
\hline Other religious restrictions. & 0.409 & -0.110 \\
\hline
\end{tabular}

\subsection{The Effect of HROs on the Aggregate Religious Restrictions}

Table 2 presents the results of my hypotheses tests using the aggregate index of religious restrictions. The first model only controls the variables in general human rights studies, and the second model additionally controls some religious variables including the percentage of Christians and Muslims, religious homogeneity and religious establishment.

HROs are helpful in the protection of aggregate religious restrictions, which includes all indicators of religious restrictions. As shown in Table 3, HROs are related to a better protection of religious rights for organizations as indicated by model 1 and 2, which is consistent with the Hypothesis 1. Substantively, one human rights organization in a country can decrease $0.04 \%$ of one standard deviation of religious restrictions; an increase on the number of human rights organizations from 1 to 139 can lead to the decrease of around $55.6 \%$ of one standard deviation of religious restrictions on average in model 1. The size of effect reduces slightly after the percentages of Christians and Muslims, 
religious homogeneity and establishment are held at constant in model 2. Around 139 HROs can decrease the restriction of religious organization by almost $46.3 \%$ of one standard deviation when these religious variables are held constant. Therefore, HROs are effective in pressuring states to change their policy and practice in religious rights.

Table 3. The Effect of Domestic Presence of HROs on Aggregate Religious Restrictions.

\begin{tabular}{|c|c|c|}
\hline & \multicolumn{2}{|c|}{ Aggregate Religious Restrictions } \\
\hline & Model 1 & Model 2 \\
\hline HROs & $\begin{array}{c}-0.032 * * * \\
(0.009)\end{array}$ & $\begin{array}{c}-0.027^{* * *} \\
(0.009)\end{array}$ \\
\hline Democracy & $\begin{array}{l}-0.023 \\
(0.018)\end{array}$ & $\begin{array}{r}-0.019 \\
(0.018)\end{array}$ \\
\hline Population (logged) & $\begin{array}{l}1.173 \text { ** } \\
(0.546)\end{array}$ & $\begin{array}{l}1.007^{*} \\
(0.534)\end{array}$ \\
\hline GDP (logged) & $\begin{array}{c}-0.633^{* * *} \\
(0.218)\end{array}$ & $\begin{array}{c}-0.653^{* * *} \\
(0.214)\end{array}$ \\
\hline GDP Growth & $\begin{array}{c}0.028^{* * *} \\
(0.008)\end{array}$ & $\begin{array}{c}0.026^{* * *} \\
(0.008)\end{array}$ \\
\hline Trade (\% GDP) & $\begin{array}{l}-0.005 \\
(0.003)\end{array}$ & $\begin{array}{c}-0.004 \\
(0.003)\end{array}$ \\
\hline Internal War & $\begin{array}{l}0.084^{*} \\
(0.050)\end{array}$ & $\begin{array}{c}0.078 \\
(0.049)\end{array}$ \\
\hline External War & $\begin{array}{c}0.046 \\
(0.159)\end{array}$ & $\begin{array}{c}0.027 \\
(0.155)\end{array}$ \\
\hline Regime Duration & $\begin{array}{c}-0.010 \\
(0.007)\end{array}$ & $\begin{array}{c}-0.008 \\
(0.007)\end{array}$ \\
\hline Judiciary Independence & $\begin{array}{c}0.111 \\
(0.128)\end{array}$ & $\begin{array}{c}0.138 \\
(0.127)\end{array}$ \\
\hline Christian (\%) & & $\begin{array}{c}-0.283 \\
(1.324)\end{array}$ \\
\hline Muslim (\%) & & $\begin{array}{c}1.671 \\
(2.593)\end{array}$ \\
\hline Religious Homogeneity & & $\begin{array}{c}0.404 \\
(0.291)\end{array}$ \\
\hline Religious Establishment & & $\begin{array}{c}5.439 * * * \\
(0.658)\end{array}$ \\
\hline N (country-year observations) & 1494 & 1494 \\
\hline $\mathrm{N}$ (countries) & 118 & 118 \\
\hline Within R-squared & 0.036 & 0.084 \\
\hline
\end{tabular}

$\overline{* * *} p<0.01{ }^{* *} p<0.05 ;{ }^{*} p<0.1$.

\subsection{The Effect of HROs on the Institutional and Individual Religious Restrictions}

Table 4 presents the results of my hypotheses tests using the institutional and individual religious restrictions variables. The first and second columns are the results for institutional religious restrictions and the third and fourth columns are the results for individual religious restrictions. Models 3 and 5 only control the variables in general human rights studies, while models 4 and 6 additionally control some religious variables including the percentages of Christians and Muslims, religious homogeneity and religious establishment. 
Table 4. The Effect of Domestic Presence of HROs on Institutional and Individual Religious Restrictions.

\begin{tabular}{|c|c|c|c|c|}
\hline & \multicolumn{2}{|c|}{ Institutional Religious Restrictions } & \multicolumn{2}{|c|}{ Individual Religious Restrictions } \\
\hline & Model 3 & Model 4 & Model 5 & Model 6 \\
\hline \multirow[t]{2}{*}{ HROs } & $-0.001^{* * *}$ & $-0.001^{* *}$ & $-0.001^{* * *}$ & $-0.001^{* * *}$ \\
\hline & $(0.0004)$ & $(0.0004)$ & $(0.0003)$ & $(0.0003)$ \\
\hline \multirow{2}{*}{ Democracy } & -0.001 & -0.0005 & -0.0005 & -0.0004 \\
\hline & $(0.001)$ & $(0.001)$ & $(0.001)$ & $(0.001)$ \\
\hline \multirow{2}{*}{ Population (logged) } & $0.071^{* * *}$ & $0.061^{* *}$ & 0.024 & 0.025 \\
\hline & $(0.027)$ & $(0.026)$ & $(0.017)$ & $(0.017)$ \\
\hline \multirow[t]{2}{*}{ GDP (logged) } & $-0.027^{* *}$ & $-0.028^{* * *}$ & -0.006 & -0.006 \\
\hline & $(0.011)$ & $(0.010)$ & $(0.007)$ & $(0.007)$ \\
\hline \multirow[t]{2}{*}{ GDP Growth } & $0.001 *$ & 0.001 & $0.001^{* *}$ & $0.001^{* * *}$ \\
\hline & $(0.0004)$ & $(0.0004)$ & $(0.0002)$ & $(0.0003)$ \\
\hline \multirow[t]{2}{*}{ Trade (\% GDP) } & -0.0002 & -0.0001 & -0.00002 & -0.00003 \\
\hline & $(0.0002)$ & $(0.0002)$ & $(0.0001)$ & $(0.0001)$ \\
\hline \multirow[t]{2}{*}{ Internal War } & 0.003 & 0.002 & $0.006^{* * *}$ & $0.006^{* * *}$ \\
\hline & $(0.002)$ & $(0.002)$ & $(0.002)$ & $(0.002)$ \\
\hline \multirow[t]{2}{*}{ External War } & -0.003 & -0.004 & 0.004 & 0.004 \\
\hline & $(0.008)$ & $(0.008)$ & $(0.005)$ & $(0.005)$ \\
\hline \multirow[t]{2}{*}{ Regime Duration } & $-0.001^{* * *}$ & $-0.001^{* * *}$ & -0.0001 & -0.0001 \\
\hline & $(0.0004)$ & $(0.0004)$ & $(0.0002)$ & $(0.0002)$ \\
\hline \multirow[t]{2}{*}{ Judiciary Independence } & 0.005 & 0.006 & $0.007 *$ & $0.008 *$ \\
\hline & $(0.006)$ & $(0.006)$ & $(0.004)$ & $(0.004)$ \\
\hline \multirow[t]{2}{*}{ Christian (\%) } & & 0.046 & & -0.064 \\
\hline & & $(0.065)$ & & $(0.043)$ \\
\hline \multirow[t]{2}{*}{ Muslim (\%) } & & 0.055 & & 0.074 \\
\hline & & $(0.127)$ & & $(0.084)$ \\
\hline \multirow[t]{2}{*}{ Religious Homogeneity } & & $0.028 *$ & & 0.008 \\
\hline & & $(0.014)$ & & $(0.009)$ \\
\hline \multirow{2}{*}{$\begin{array}{c}\text { Religious } \\
\text { Establishment }\end{array}$} & & $0.319^{* * *}$ & & -0.029 \\
\hline & & $(0.032)$ & & $(0.021)$ \\
\hline $\begin{array}{c}\text { N (country-year } \\
\text { observations) }\end{array}$ & 1494 & 1494 & 1494 & 1494 \\
\hline $\mathrm{N}$ (countries) & 118 & 118 & 118 & 118 \\
\hline Within R-squared & 0.036 & 0.103 & 0.023 & 0.027 \\
\hline
\end{tabular}

*** $p<0.01 ;{ }^{* *} p<0.05 ; * p<0.1$.

The domestic presence of HROs is effective in protecting both the institutional and individual religious restrictions, which is consistent with Hypotheses 2 and 3. For religious institutions, one human rights organization in a country can decrease $0.1 \%$ of one scale of institutional religious restriction index, which is $0.25 \%$ of one standard deviation; an increase on the number of human rights organization from 1 to 139 can lead to the decrease of $13.9 \%$ of one scale of institutional religious restriction, which is around $34.75 \%$ of one standard deviation of institutional religious restrictions on average. After holding constant the percentages of Christian and Muslim, the level of religious homogeneity and religious establishment status, the effect size remains the same.

HROs can also mitigate the oppression from the government for religious individuals. According to models 5 and 6, one human rights organization in a country can reduce $0.1 \%$ of one scale of individual religious restriction index, which is $0.5 \%$ of one standard deviation; an increase on the number of human rights organizations from 1 to 139 can lead to the decrease of $13.9 \%$ of one scale of individual religious restriction, which is around $69.5 \%$ of one standard deviation of individual religious restrictions. The effect size also remains the same, after holding the percentages of Christian and Muslim, the level of religious homogeneity, and religious establishment status constant.

Thus, HROs can reduce both institutional and individual religious restrictions, even though the underlying mechanisms might be different, based on the distinct nature of 
these two dimensions of human rights. Religious institutions are visible, thus HROs provide support and resources to religious institutions and mediate between them and the government to reduce the repercussions from political disruptions in a direct way. Religious individual restrictions are covert, HROs can also transmit information they gather on religious individual restrictions to overseas and pressure states from the third parties such as UN and some western democracies. HROs can also provide knowledge and resources to individuals and mobilize them to fight for their rights.

\subsection{Other Variables Explaining Variation in Religious Institutional and Individual Restrictions}

Even though the control variables are not the focus of this study, it is necessary to explore how they are related to the different levels of religious institutional and individual restrictions. Based on models 3-6, those control variables are associated with institutional and individual restrictions differently. Therefore, they support argument that institutional and individual religious restrictions are inherently different, and the distinctions between the two dimensions of human rights should be further examined in the future studies.

Some factors have a significant effect on the institutional religious restrictions but not on individual religious restrictions. The size of GDP in a country is negatively related to the institutional religious restrictions. It is consistent with literature that the bigger the size of the economy is, the lower the religious restrictions are (Mitchell and McCormick 1988; Keith et al. 2009; Grim and Finke 2010). The models also indicate that stable regimes have a lower level of institutional religious restrictions (Grim and Finke 2010). However, both variables are not related to the individual religious restrictions. The models also show that countries with an established religion or a homogenous religious scene have a higher level of restrictions on institutions, because governments are more likely to adopt favoritism towards the established or majority religion in a society in exchange for their support. Restrictions on religious institutions also tend to be higher when the countries have a bigger population. Literature in human rights indicates that there is a higher chance for the occurrence of human rights violations when the population is big (Poe and Tate 1994; Poe et al. 1999; Keith et al. 2009; Richards et al. 2001). It is also true that coders are more likely to find restrictions in a more populous country, where the number of religious people and institutions are also bigger. Interestingly, population size is not related to the individual religious restrictions.

Some other factors are associated with a higher level of religious restrictions for individuals but not for institutions. When there are internal wars, individuals in a society are more likely to be oppressed. Therefore, human rights, including religious freedom, are more likely to be violated. Even though the polity score measure of democracy is not associated with individual religious restrictions, judiciary independence is. Surprisingly, when the judiciary branch becomes more independent, the level of individual religious freedom is actually lower. In addition, economic growth rate is positively related to the level of individual religious restrictions. In other words, individual religious restrictions tend to be higher in countries where the economic growth rate is high. Poe and Tate (1994) explain that rapid economic growth also can increase instability which induce the states to resort to coercion. The only variable seems to be able to reduce the individual religious restrictions is the HROs. Therefore, the study on HROs is of great significance in the study of individual religious restrictions.

\section{Conclusions and Discussion}

This study finds that religious restrictions have two dimensions: institutional and individual restrictions with an exploratory factor analysis and provides evidence that these two dimensions of religious restrictions should be treated separately in future studies.

This study also examines the effects of HROs on the protection of religious freedom and its two dimensions over time. The mere presence of HROs within a country not only reduces overall religious restrictions; that presence also alleviates both institutional and individual religious restrictions in the 14 years covered. Based on the distinct features of 
religious institutions versus individual adherents, restrictions on the former are more overt while more covert on the latter. Therefore, the approach HROs adopt might be more direct for institutions and more indirect for individuals. Domestic HROs play an important role in working with religious institutions to pressure states to change their policies and practices in religious freedom. HROs channel resources to religious institutions to engage in legal or social movement activism for religious freedom. Protection of individual religious freedom might entail a bottom-up process, in which domestic institutions transmit information to HROs on repression or persecution of individuals, which then can name and shame violating states on the international stage. In this way domestic institutions, working in concert with international NGOs and sympathetic states, can help empower and mobilize individuals to fight powerful states to protect their rights through litigation or social movement activism.

This study has great theoretical implications. It expands the current literature on HROs and human rights by focusing on religious rights and their two dimensions. The findings indicate that the domestic presence of HROs is effective in the religious rights protection, which increases with their number and density, a finding consistent with most current literature on other kinds of rights protection. A more textured finding is that HROs are critically important both in the protection of institutional and individual dimensions of religious freedom, but through different underlying mechanisms. HROs employ top-down and bottom-up processes, using direct and indirect approaches for religious institutions and individuals, respectively. This indicates the need to differentiate individual and institutional rights in international human rights studies, both to advance more novel theories and develop more practical policies in human rights protection.

This study also has a great implication for policies to advance international human rights protection. The domestic presence of HROs is useful in protecting the rights of religious institutions and individuals. Among all the variables tested in this study, HROs are the only variable effective addressing religious individual restrictions. Thus, we need to acknowledge that HROs are improving the protection of human rights on the grassroots level, despite of the lack of enforcement in international human rights regimes. As moral agents, transnational advocacy networks play an important role to pressure states to change how they treat their citizens with the vital information and tangible resources. HROs and other international actors need to strengthen existing strategies and develop new ones that hold states accountable for violations.

There are also a few limitations in this study which can be addressed by future studies. The first lies in the limitation of the data, which only covers 1990 to 2003 (given the available data on HROs). The results would have stronger internal validity if the years covered in this study are longer. Future studies can collect more data with longer time span and test the same theories in this study. Second, measurement on HROs can be improved. As the study done by (Murdie and Peksen 2015), the HROs with a specific focus on certain kind(s) of human rights can be more effective in combating the corresponding human rights violations. A way can improve this study is to collect the data on the number of religious HROs on religious freedom across years and countries. The relationships found in this study might be strengthened with these new measures and data.

Funding: This research received no external funding.

Data Availability Statement: The data presented in this study are openly available in Harvard Dataverse at https:/ / doi.org/10.7910/DVN/1LHW5S, V1.

Acknowledgments: My thanks to Allen Hertzke, Roger Finke, Colin Barry, Religions editors, and anonymous reviewers for their helpful comments and suggestions on previous iterations of this article.

Conflicts of Interest: The author declares no conflict of interest. 


\section{References}

Bagwell, Stephen, and Chad Clay. 2017. Capable of Shame? HRO Shaming, State Capabilities, and Government Respect for Physical Integrity. Paper presented at Annual Meeting of the International Studies Association, Baltimore, MD, USA, February 22-25.

Bell, Sam R., K. Chad Clay, and Amanda Murdie. 2012. Neighborhood Watch: Spatial Effects of Human Rights INGOs. The Journal of Politics 74: 354-68. [CrossRef]

Brysk, Alison. 1993. From Above and Below: Social Movements, the International System and Human Rights in Argentina. Comparative Political Studies 26: 259-85. [CrossRef]

Cole, Wade M., and Francisco O. Ramirez. 2013. Conditional Decoupling: Assessing the Impact of National Human Rights Institutions, 1981 to 2004. American Sociological Review 78: 702-25. [CrossRef]

Dai, Xinyuan. 2005. Why Comply? The Domestic Constituency Mechanism. International Organization 59. Available online: http: / / www.journals.cambridge.org/abstract_S0020818305050125 (accessed on 2 April 2017).

Davis, David R., Amanda Murdie, and Coty Garnett Steinmetz. 2012. 'Makers and Shapers': Human Rights INGOs and Public Opinion. Human Rights Quarterly 34: 199-224. [CrossRef]

DeMeritt, Jacqueline H. R. 2012. International Organizations and Government Killing: Does Naming and Shaming Save Lives? International Interactions 38: 597-621. [CrossRef]

Donnelly, Jack. 2013. Universal Human Rights in Theory and Practice. Ithaca: Cornell University Press.

Englehart, Neil A. 2009. State Capacity, State Failure, and Human Rights. Journal of Peace Research 46: 163-80. [CrossRef]

Fariss, Christopher J. 2017. The Changing Standard of Accountability and the Positive Relationship between Human Rights Treaty Ratification and Compliance. British Journal of Political Science 48: 239-71. [CrossRef]

Finke, R. 2013. Presidential Address Origins and Consequences of Religious Freedoms: A Global Overview. Sociology of Religion 74: 297-313. [CrossRef]

Finke, Roger, and Robert R. Martin. 2014. Ensuring Liberties: Understanding State Restrictions on Religious Freedoms: State restrictions on religious freedoms. Journal for the Scientific Study of Religion 53: 687-705. [CrossRef]

Finke, Roger, Robert R. Martin, and Jonathan Fox. 2017. Explaining Discrimination against Religious Minorities. Politics and Religion 10: 389-416. [CrossRef]

Fox, Jonathan. 2000. Religious Causes of Discrimination against Ethno-Religious Minorities. International Studies Quarterly 44: 423-50. [CrossRef]

Fox, Jonathan. 2001. Religion as an Overlooked Element of International Relations. International Studies Review 3: 53-73. [CrossRef]

Fox, Jonathan. 2008. State Religious Exclusivity and Human Rights. Political Studies 56: 928-48. [CrossRef]

Fox, Jonathan. 2014. Is It Really God's Century? An Evaluation of Religious Support and Discrimination from 1990 to 2008. Politics and Religion 7: 4-27. [CrossRef]

Fox, Jonathan. 2015. Religious Freedom in Theory and Practice. Human Rights Review 16: 1-22. [CrossRef]

Fox, Jonathan. 2018. An Introduction to Religion and Politics: Theory and Practice. London: Routledge.

Fox, Jonathan. 2021. What Is Religious Freedom and Who Has It? Social Compass 1: 1.

Franklin, James C. 2008. Shame on You: The Impact of Human Rights Criticism on Political Repression in Latin America. International Studies Quarterly 52: 187-211. [CrossRef]

Gill, Anthony. 2007. The Political Origins of Religious Liberty, 1st ed. Cambridge: Cambridge University Press.

Goodman, Ryan, and Derek Jinks. 2004. How to Influence States: Socialization and International Human Rights Law. Duke Law Journal 54: 621-703.

Grim, Brian J, and Roger Finke. 2006. International Religion Indexes: Government Regulation, Government Favoritism, and Social Regulation of Religion. Interdisciplinary Journal of Research on Religion 2: 38.

Grim, Brian J., and Roger Finke. 2010. The Price of Freedom Denied: Religious Persecution and Conflict in the Twenty-First Century. Cambridge: Cambridge University Press.

Hafner-Burton, Emilie M. 2008. Sticks and Stones: Naming and Shaming the Human Rights Enforcement Problem. International Organization 62: 689-716. [CrossRef]

Hafner-Burton, Emilie M., and Tsutsui. 2005. Trading Human Rights: How Preferential Trade Agreements Influence Government Repression. International Organization 59. Available online: http://www.journals.cambridge.org/abstract_S0020818305050216 (accessed on 2 April 2017).

Hathaway, Oona A. 2002. Do Human Rights Treaties Make a Difference? The Yale Law Journal 111: 1935. [CrossRef]

Hendrix, Cullen S., and Wendy H. Wong. 2013. When Is the Pen Truly Mighty? Regime Type and the Efficacy of Naming and Shaming in Curbing Human Rights Abuses. British Journal of Political Science 43: 651-72. [CrossRef]

Keck, Margaret E., and Kathryn Sikkink. 1999. Transnational Advocacy Networks in International and Regional Politics. International Social Science Journal 51: 89-101. [CrossRef]

Keith, Linda Camp, C. Neal Tate, and Steven C. Poe. 2009. Is The Law a Mere Parchment Barrier to Human Rights Abuse? The Journal of Politics 71: 644-60. [CrossRef]

Khagram, Sanjeev, James V. Riker, and Kathryn Sikkink. n.d. Restructuring World Politics: Transnational Social Movements, Networks, and Norms. Minneapolis: University of Minnesota Press.

Krain, Matthew. 2012. J'accuse! Does Naming and Shaming Perpetrators Reduce the Severity of Genocides or Politicides? International Studies Quarterly 56: 574-89. [CrossRef] 
Meernik, James, Rosa Aloisi, Marsha Sowell, and Angela Nichols. 2012. The Impact of Human Rights Organizations on Naming and Shaming Campaigns. Journal of Conflict Resolution 56: 233-56. [CrossRef]

Meyer, John W., John Boli, George M. Thomas, and Francisco O. Ramirez. 1997. World Society and the Nation-State. American Journal of Sociology 103: 144-81. [CrossRef]

Mitchell, Neil J., and James M. McCormick. 1988. Economic and Political Explanations of Human Rights Violations. World Politics 40: 476-98. [CrossRef]

Murdie, Amanda M., and David R. Davis. 2012. Shaming and Blaming: Using Events Data to Assess the Impact of Human Rights INGOs1: Shaming and Blaming. International Studies Quarterly 56: 1-16. [CrossRef]

Murdie, Amanda, and Dursun Peksen. 2015. Women's Rights INGO Shaming and the Government Respect for Women's Rights. The Review of International Organizations 10: 1-22. [CrossRef]

Murdie, Amanda. 2014. The Ties That Bind: A Network Analysis of Human Rights International Nongovernmental Organizations. British Journal of Political Science 44: 1-27. [CrossRef]

Peksen, Dursun. 2009. Better or Worse? The Effect of Economic Sanctions on Human Rights. Journal of Peace Research 46: 59-77. [CrossRef]

Peksen, Dursun. 2012. Does Foreign Military Intervention Help Human Rights? Political Research Quarterly 65: 558-71. [CrossRef]

Poe, Steven C., and C. Neal Tate. 1994. Repression of Human Rights to Personal Integrity in the 1980s: A Global Analysis. American Political Science Review 88: 853-72. [CrossRef]

Poe, Steven C., C. Neal Tate, and Linda Camp Keith. 1999. Repression of the Human Right to Personal Integrity Revisited: A Global Cross-National Study Covering the Years 1976-1993. International Studies Quarterly 43: 291-313.

Rasler, Karen. 1986. War Accommodation, and Violence in the United States, 1890-1970. The American Political Science Review 80: 921-45. [CrossRef]

Richards, David L., Ronald D. Gelleny, and David H. Sacko. 2001. Money with a Mean Streak? Foreign Economic Penetration and Government Respect for Human Rights in Developing Countries. International Studies Quarterly 45: 219-39. [CrossRef]

Risse, Thomas, Stephen C. Ropp, and Kathryn Sikkink. 1999. The Power of Human Rights: International Norms and Domestic Change. Cambridge: Cambridge University Press, pp. 1949-99.

Sandal, Nukhet, and Jonathan Fox. 2013. Religion in International Relations Theory: Interactions and Possibilities. London: Routledge.

Sarkissian, Ani. 2015. The Varieties of Religious Repression: Why Governments Restrict Religion, 1st ed. Oxford and New York: Oxford University Press.

Scolnicov, Anat. 2010. The Right to Religious Freedom in International Law: Between Group Rights and Individual Rights. Oxfordshire: Routledge.

Sikkink, Kathryn. 1993. Human Rights, Principled Issue-Networks, and Sovereignty in Latin America. International Organization 47: 411-41. [CrossRef]

Simmons, Beth A. 2009. Mobilizing for Human Rights: International Law in Domestic Politics. Cambridge: Cambridge University Press.

Simmons, Beth A., Frank Dobbin, and Geoffrey Garrett. 2008. The Global Diffusion of Markets and Democracy. Cambridge: Cambridge University Press.

Smith, Jackie, and Dawn Wiest. 2005. The Uneven Geography of Global Civil Society: National and Global Influences on Transnational Association. Social Forces 84: 621-52. [CrossRef]

Stark, Rodney, and Roger Finke. 2000. Acts of Faith: Explaining the Human Side of Religion. Oakland: University of California Press.

Tsutsui, Kiyoteru, and Christine Min Wotipka. 2004. Global Civil Society and the International Human Rights Movement: Citizen Participation in Human Rights International Nongovernmental Organizations. Social Forces 83: 587-620. [CrossRef]

Tsutsui, Kiyoteru. 2006. Redressing Past Human Rights Violations: Global Dimensions of Contemporary Social Movements. Social Forces 85: 331-54. [CrossRef] 